\title{
Design and In Vitro Evaluation of Eudragit-Based Extended Release Diltiazem Microspheres for Once- and Twice-Daily Administration: The Effect of Coating on Drug Release Behavior
}

\author{
Günde Bir ve İki Kez Uygulama için Eudragit Esaslı Uzatılmış Salımlı \\ Diltiazem Mikrokürelerin Tasarımı ve In Vitro Değerlendirilmesi: \\ Kaplamanın Etken Madde Salım Şekline Etkisi
}

\author{
(D) Noushin BOLOURCHIAN*, (D) Maryam BAHJAT \\ Department of Pharmaceutics and Pharmaceutical Nanotechnology, School of Pharmacy, Shahid Beheshti University of Medical Sciences, Tehran, Iran
}

\begin{abstract}
Objectives: The aim of this investigation was to develop an extended release formulation of diltiazem hydrochloride (DL) for once- and twice-daily administration, based on Eudragit (Eud) RL and RS microspheres using emulsion solvent evaporation.

Materials and Methods: Formulations with different drug-polymer concentrations were produced and characterized in terms of yield, encapsulation efficiency (EE), particle size, and surface morphology. The drug release and thermal behavior of the microspheres were also investigated. Selected microspheres were then coated with Eud RS by continuous solvent evaporation, in order to modify the microspheres' properties and burst release. Results: According to the results, the EE was in the range of $56 \%-93 \%$ for uncoated microspheres. The mean particle size of microspheres was different from 470 to above $1000 \mu \mathrm{m}$, based on various formulation variables. No difference was observed between the mean size of particles prepared with Eud RL and Eud RS. Microspheres showed sustained release behavior, which was affected by the drug:polymer ratio as well as particle size. Coating the microspheres not only improved the EE values ( $82 \%-92 \%)$ but also reduced the mean dissolution rate as well as the burst release.

Conclusion: Microspheres prepared with DL:Eud RL ratios of 1:3 and 1:4 showed release profiles in accordance with the USP criteria for a DL extended release product for dosing every 12 and 24 h, respectively.
\end{abstract}

Key words: Coating, diltiazem hydrochloride, Eudragit RL and RS, extended release, microspheres

ÖZ

Amaç: Bu araştırmanın amacı, emülsiyon çözücü buharlaştırma kullanarak hazırlanan Eudragit (Eud) RL ve RS mikro küreleri ile günde bir ve iki kez uygulama için diltiazem hidroklorürün (DL) uzatılmış salım formülasyonunu geliştirmektir.

Gereç ve Yöntemler: Farklı etken madde-polimer konsantrasyonlarına sahip formülasyonlar üretilmiş ve verim, enkapsülasyon etkinliği (EE), partikül büyüklüğü ve yüzey morfolojisi açısından karakterize edilmiştir. Mikrokürelerin etken madde salınımı ve termal davranışı da incelenmiştir. Seçilen mikro küreler daha sonra mikro kürelerin özelliklerini modifiye ve hızlı ilk salınımını değiştirmek için sürekli çözücü buharlaştırma yoluyla Eud RS ile kaplanmıştır.

Bulgular: Sonuçlara göre, kaplanmamış mikroküreler için EE \%56 -\%93 aralığındadır. Mikrokürelerin ortalama partikül büyüklüğü, çeşitli formülasyon değişkenlerine bağlı olarak 470 ila 1000 um'nin üzerinde olmuştur. Eud RL ve Eud RS ile hazırlanan partiküllerin ortalama ortalama partikül büyüklüğü arasında bir fark gözlenmemiştir. Mikroküreler, etken madde: polimer oranının yanı sıra partikül boyutundan etkilenen sürekli salım davranışı göstermiştir. Mikrokürelerin kaplanması sadece EE değerlerini iyileștirmemiş (\%82 -\%92), aynı zamanda hızlı ilk çıkış yanı sıra ortalama çözünme oranınıda (MDR) azaltmıştır.

*Correspondence: E-mail: bolourchian@sbmu.ac.ir, Phone: +982188200072 ORCID-ID: orcid.org/0000-0002-8178-1624

Received: 22.04.2018, Accepted: 20.06.2018

๑Turk J Pharm Sci, Published by Galenos Publishing House. 
Sonuç: 1:3 ve 1:4 oranlarında DL:Eud RL mikroküreler, sırasıyla her 12 ve 24 saatte bir dozlama için DL uzatılmış salım ürünü için USP kriterlerine uygun salım profilleri göstermiştir.

Anahtar kelimeler: Kaplama, diltiazem hidroklorür, Eudragit RL ve RS, uzatılmış salınım, mikroküreler

\section{INTRODUCTION}

Diltiazem hydrochloride (DL) is a highly soluble calcium channel blocker drug that is used in the treatment of high blood pressure and angina pectoris. Due to its short elimination half-life of 2-5 $\mathrm{h}$, the conventional oral dosage forms are administered 3-4 times a day, to maintain an effective plasma concentration, which results in low and variable bioavailability. ${ }^{2}$ Using a sustained release form of this medication is vital for its efficacy by achieving relative constant blood concentrations and improving the clinical efficacy of the drug, as well as patient compliance.

However, along with the benefits of using extended release single-unit tablets, there are some limitations for these systems, such as the dose adjustment problem and the effect of food on drug release. Moreover, breaking the tablets before taking them could cause different release behavior and serious side effects. ${ }^{3}$ The above-mentioned problems could be overcome using microspheres as multiple-unit dosage forms. Microspheres are uniformly distributed in the gastrointestinal tract and result in more uniform drug absorption, limited fluctuation within a therapeutic range, decreased dose frequency, and reduced patient-to-patient variability. ${ }^{4}$

The physical properties and release behavior of microspheres are dependent on different factors such as drug and polymer nature as well as the method of manufacturing. According to the literature, the existence of drug particles on the surface and particles embedded in the surface layers as well as high porosity of microspheres are considered the main reasons for initial burst release. Coating of microspheres is one of the approaches to reduce the burst release and modify the drug release behavior. ${ }^{5}$ Preparation and separation of initial microspheres and then using them in a separate coating process would be time and cost consuming. Therefore, application of a continuous preparation and coating process for microspheres seems to be preferable.

To date, modified-release microspheres of DL using different polymers and methods were developed in order to extend its clinical effects. 2,6-11 Only a few studies were performed on the preparation of Eudragit (Eud) RS-based DL microspheres by solvent evaporation. ${ }^{12-14}$

The objective of the present research was to design and evaluate DL-loaded Eud RL and RS matrix-type microspheres as extended release systems for both once- and twice-daily administration, in order to reduce its dosing frequency. With the aim of achieving both systems, different drug-polymer concentrations were applied and examined. In addition, the effect of coating of microspheres by Eud RS on drug release behavior and the burst effect was also evaluated. Emulsion solvent evaporation was used for microsphere preparation as well as continuous coating. This is a simple method that has been used to prepare microspheres of different soluble and insoluble compounds. ${ }^{15-17}$

\section{MATERIALS AND METHODS}

\section{Materials}

DL powder (Zambon Group SPA, Italy), Eud RL and RS 100 (Röhm Pharma GmbH, Germany), span 60 (Sigma-Aldrich, St. Louis, MO, USA), n-hexane (Carlo Erba, France), and liquid paraffin (Merck, Germany) were used in this study. The materials and excipients used in preparing the microspheres were of pharmacopoeial grade.

\section{Microsphere preparation}

DL-loaded Eud RL and RS microspheres were produced by emulsion solvent evaporation. ${ }^{18}$ Different amounts of drug and polymer were dissolved in $3 \mathrm{~mL}$ of ethanol (dispersed phase), which was then slowly (at the rate of $1 \mathrm{~mL} / \mathrm{min}$ ) added to a beaker containing a mixture of $50 \mathrm{~mL}$ of liquid paraffin and $0.1 \%$ $\mathrm{w} / \mathrm{v}$ span 60 (continuous phase) with stirring at $500 \mathrm{rpm}$ using a mechanical stirrer (IKA, Germany). The mixture was stirred until the organic solvent evaporated completely. The prepared microspheres were collected by filtration and washed three times with $n$-hexane until all the paraffin was removed. Finally, the microspheres were dried at room temperature for $24 \mathrm{~h}$ and kept in air-tight containers for further studies.

\section{Coating of microspheres}

A one-step continuous solvent evaporation technique was used for the coating process. Primary microspheres were prepared by the above-mentioned method, but before completing the process and collecting the microspheres a 3.3\% w/v Eud RS ethanolic solution was added dropwise to the continuous phase and stirred until complete solvent evaporation. ${ }^{9}$ The other steps were similar to the previous method.

\section{Characterization of microspheres}

The prepared microspheres were characterized in terms of yield value, encapsulation efficiency (EE), morphology, drug release, particle size, and thermal analysis. The yield value of each formulation was calculated by the following equation: ${ }^{19}$

Yield value(\%) = (weight of dried microspheres/total solid material amount in the dispersed phase) $\times 100$

\section{Drug content}

Ten milligrams of dried microspheres was accurately weighed and transferred to a beaker containing $10 \mathrm{~mL}$ of methanol and stirred for $15 \mathrm{~min}$ to dissolve the microspheres completely. The solution was analyzed for DL content by a UV spectrophotometer (Shimadzu UV1201, Japan) at $240 \mathrm{~nm}$ after dilution. The drug loading and EE were calculated using the following equations: ${ }^{20}$ 
Drug loading $(\%)=$ (weight of drug in microspheres/weight of microspheres $) \times 100$

Drug $E E(\%)=$ (actual drug loading/theoretical drug loading $) \times 100$

\section{In vitro drug release}

Drug release of all microspheres was carried out using a USP type II dissolution test apparatus (Erweka DT6R, Germany) in $900 \mathrm{~mL}$ of phosphate buffer solution ( $\mathrm{pH} 7.2$ ) at $37 \pm 0.5^{\circ} \mathrm{C}$ at $50 \mathrm{rpm}$ (in accordance with the USP test number 5 for DL extended release form dosing every $12 \mathrm{~h}$ ). Then $3 \mathrm{~mL}$ of the medium was withdrawn at predetermined time intervals and replaced with the same amount of fresh dissolution medium after each sampling. The sample solutions were analyzed for drug content at $240 \mathrm{~nm}$ by a UV spectrophotometer.

The dissolution test was also performed on selected microspheres in compliance with the USP test number 2 for DL extended release form dosing every $24 \mathrm{~h}$, using an apparatus II at $100 \mathrm{rpm}$ and $900 \mathrm{~mL}$ of dissolution medium (distilled water) for $15 \mathrm{~h}$. All experiments were performed in triplicate for each formulation.

All formulations were compared using different dissolution parameters. ${ }^{21}$ Mean dissolution time (MDT), which was applied to analyze dissolution profiles, was calculated arithmetically by the following equation:

MDT $=\frac{\sum_{i=1}^{n} \text { ti } \Delta M i}{\sum_{i=1}^{n} \Delta M i}$

where $\Delta \mathrm{M}_{\mathrm{i}}$ is the fraction of drug released in time $t_{i}$ (calculated by $\left.\left(t_{i}+t_{i-1}\right) / 2\right)$ and $i$ is the sample number.

In addition, the area under the dissolution curve [dissolution efficiency (DE)] was calculated by the formula below:

$D E=\frac{\int_{0}^{t} y \cdot d t}{y 100 \cdot t} \times 100$

where $y$ is the percentage of drug dissolved at time t. Mean dissolution rate (MDR) was also calculated based on the following equation:

$\operatorname{MDR}=\frac{\sum_{i=1}^{n} \Delta M i / \Delta t}{n}$

where $\Delta t$ is the time at the midpoint between $t$ and $t_{-1}$ and $n$ is the number of dissolution sample times.

\section{Particle size}

The mean particle size of the DL microspheres was determined by optical microscopy. At least 200 microspheres were analyzed for each preparation and the mean diameter was calculated.

\section{Surface morphology}

The appearance and surface morphology of microspheres were evaluated by scanning electron microscopy [scanning electron microscopy (SEM), Philips XL30, the Netherlands]. The microspheres were attached to a specimen holder with doublesided adhesive tape and coated under vacuum by gold sputter coater (Bal-Tec SCD 005, Switzerland) prior to observation.

\section{Differential scanning calorimetry}

Differential scanning calorimetry (DSC) analysis of the drug, polymer, selected DL-loaded microspheres, and related physical mixture was conducted. After calibrating the apparatus (Shimadzu DSC-60, Japan) by indium standard, accurately weighed samples $(5 \mathrm{mg}$ ) were placed in sealed aluminum pans. The containers were placed in the DSC apparatus and heated at a constant rate of $10 /$ min over a temperature range of 25 to $300^{\circ} \mathrm{C}$. An empty standard aluminum pan was used as reference.

\section{Statistical analysis}

Statistical analysis of the different variables was carried out using ANOVA followed by Tukey's post hoc test. Significance was tested at the 0.05 level of probability.

\section{RESULTS AND DISCUSSION}

DL microspheres were successfully prepared by emulsion solvent evaporation using ethanol as the drug-polymer solvent (dispersed phase) and a liquid paraffin-span 60 mixture as the continuous phase. The yield value was in the range of $62.8 \%$ $92.4 \%$ for the initial microspheres and $81.3 \%-97.6 \%$ for the Eud RS-coated microparticles.

\section{Characterization of microspheres}

\section{Encapsulation efficiency and particle size}

Table 1 shows the composition and properties of the Eud $\mathrm{RL}$ - and RS-based microspheres prepared with different drug:polymer ratios. Increasing the amount of Eud RL from 300 to $800 \mathrm{mg}$ led to a $25 \%$ enhancement in the EE values. In fact, the size of emulsion droplets was increased due to the higher viscosity of the polymeric solution, which in turn decreased the surface area and also drug molecule transport from dispersed to continuous phases. ${ }^{22}$ The particle size of those microspheres was also increased significantly ( $p<0.001)$, which was expected. Similar results were obtained for the microspheres prepared with higher DL concentrations. Based on the results (Table $1)$, there is a significant difference between the EE values of M8L and M4L ( $p$ <0.05). In addition, using higher drug:polymer ratios resulted in significantly $(p<0.001)$ increased particle size. Although the effect of polymer concentration on particle size seemed to be more than that of the drug, the results revealed that in certain drug concentrations its effect on particle size cannot be neglected.

The application of various drug:polymer concentrations with the same ratio (M1L, M2L, and $M 7 \mathrm{~L}$ ) resulted in microspheres with different EEs and mean particle sizes. An increase of $20 \%$ was found for the EE value of M7L (higher DL-Eud RL concentration) compared to $\mathrm{M} 1 \mathrm{~L}$ and $\mathrm{M} 2 \mathrm{~L}$. In other words, an appropriate simultaneous increase in drug and polymer concentrations led to more drug entrapment in the microspheres. The same trend was also observed for microparticles size, which could be attributed to the higher viscosity and emulsion droplet size of this formulation. However, the difference observed between $\mathrm{M} 2 \mathrm{~L}$ and M1L was far smaller. 
By changing the polymer type from Eud RL to Eud RS (Table 1), no difference was observed in EE \% for lower drug:polymer concentrations (M1L and M1S). However, the opposite was found for the formulations prepared with higher drug:polymer concentrations, in which M2S showed an improved EE value compared to $\mathrm{M} 2 \mathrm{~L}$, which is in accordance with some reports in the literature. ${ }^{23,24}$ Eud $\mathrm{RL}$ is more permeable and the diffusion of drug molecules from the droplets to the surrounding medium during the preparation process is more probable than with Eud RS. In addition, the repulsion between the quaternary ammonium groups of Eud RL and the cationic drug could facilitate DL removal to the external phase and reduce the EE.

According to the results, coating of microspheres improved the EE \% significantly ( $p<0.001)$ compared to the uncoated microspheres (Table 2). It is probable that application of the Eud RS coating on the surface of the initial microspheres prevents the drug molecules' transport to the emulsion external phase during the preparation process. Meanwhile, no difference was observed in the EE values of the coated microspheres with different inner polymers. As was expected, the mean particle size of the microparticles was increased following the coating process. The higher mean particle size of M2LS and M2SS compared to M1LS and M1SS was related to the higher inner polymer concentration used to prepare the initial microspheres. SEM

The SEM micrographs (Figure 1) show that the microspheres prepared in the presence of a lower polymer concentration (M2L) were more spherical with wrinkled surfaces compared to M5L (higher polymer amount). Using a higher DL concentration in the formulations, did not affect the microspheres' shape, but increased their roughness mainly due to the existence of drug crystals on the surface layers of the microspheres. No difference was observed between the microspheres prepared with Eud RL and RS (M1L and M1S) in terms of shape or surface properties, which was in accordance with previous research. ${ }^{24}$ Based on the results, following the coating of microspheres, they were still spherical with more uniform surfaces compared to the initial uncoated microparticles. The study of the surface morphology of M1LS and M1SS (Figure 1) confirmed the absence of drug crystals on the surface of the microparticles and suitable coverage of the initial microspheres during the continuous coating process.

\section{Drug release studies}

The release profiles of $D L$ from microspheres prepared with different formulations are presented in Figure 2. Based on the results, the drug release rate decreased apparently with increasing polymer concentration (Figure $2 \mathrm{a}$ ). The $\mathrm{DL}$ released after $3 \mathrm{~h}$ of the experiment for M2L and M5L was $73.28 \%$ and $26.09 \%$, respectively. This trend was also observed in MDR and DE values (Table 1). Furthermore, decreasing the drug release rate led to an increase in MDT values. In fact, a higher polymer concentration resulted in larger particle size with less surface

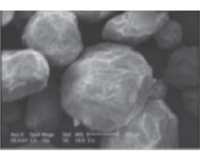

$\mathrm{M} 2 \mathrm{~L}$

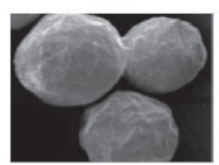

M4L

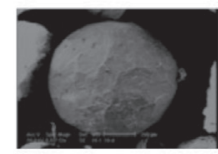

M7L

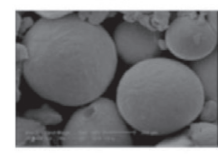

MILS

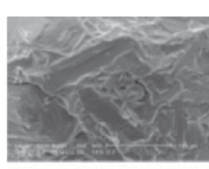

M2L surface

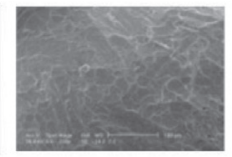

M4L surface

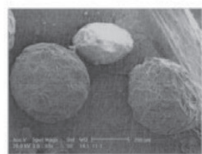

M1L

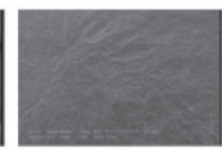

M1LS surface

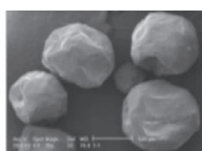
MSL

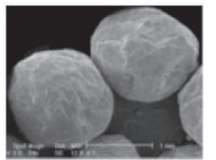

M8L

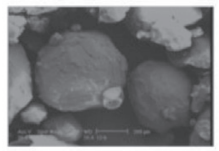

M1S

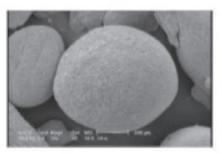

M1SS

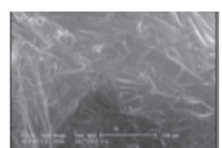

M5L surface

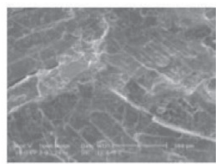

M8L surface

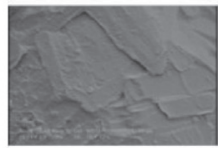

M1S surface

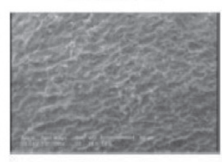

M1SS surface
Figure 1. Scanning electron microscopy micrographs of different microspheres and their surfaces

Table 1. Composition and physicochemical properties of diltiazem hydrochloride microspheres (mean \pm standard deviation, $\mathrm{n}=3$ )

\begin{tabular}{llllllll} 
Formulation & $\begin{array}{l}\text { Drug } \\
(\mathrm{mg})\end{array}$ & Polymer $(\mathrm{mg})$ & $\mathrm{EE}^{\mathrm{c}}(\%)$ & $\begin{array}{l}\text { Mean particle size } \\
(\mu \mathrm{m})\end{array}$ & $\mathrm{MDT}^{\mathrm{d}}(\mathrm{min})$ & $\mathrm{DE}^{\mathrm{e}}(\%)$ & $\mathrm{MDR}^{\mathrm{f}}\left(\% \mathrm{~min}^{-1}\right)$ \\
\hline M1L & 100 & 150 & $61.43 \pm 1.33$ & $452.9 \pm 7.29$ & $82.45 \pm 4.17$ & $83.78 \pm 0.98$ & $0.331 \pm 0.005$ \\
\hline M2L & 200 & 300 & $62.15 \pm 1.09$ & $513.8 \pm 10.09$ & $94.38 \pm 4.05$ & $75.29 \pm 0.58$ & $0.210 \pm 0.004$ \\
\hline M3L & 200 & 500 & $56.62 \pm 3.75$ & $620.0 \pm 5.82$ & $150.70 \pm 6.77$ & $74.96 \pm 0.54$ & $0.174 \pm 0.007$ \\
\hline M4L & 200 & 600 & $81.46 \pm 2.60$ & $665.7 \pm 6.71$ & $197.11 \pm 5.62$ & $61.43 \pm 1.11$ & $0.086 \pm 0.004$ \\
\hline M5L & 200 & 800 & $87.70 \pm 3.57$ & $720.1 \pm 12.58$ & $210.27 \pm 2.34$ & $54.00 \pm 1.19$ & $0.068 \pm 0.006$ \\
\hline M6L & 300 & 600 & $82.18 \pm 0.84$ & $745.9 \pm 5.58$ & $235.95 \pm 7.86$ & $58.29 \pm 1.09$ & $0.064 \pm 0.002$ \\
\hline M7L & 400 & 600 & $84.97 \pm 3.53$ & $813.2 \pm 2.33$ & $201.50 \pm 4.26$ & $66.98 \pm 0.43$ & $0.147 \pm 0.005$ \\
\hline M8L & 500 & 600 & $92.86 \pm 3.90$ & $1027.3 \pm 6.50$ & $114.94 \pm 6.45$ & $80.78 \pm 1.91$ & $0.246 \pm 0.007$ \\
\hline M1S ${ }^{b}$ & 100 & 150 & $59.53 \pm 1.19$ & $463.5 \pm 4.05$ & $116.74 \pm 5.05$ & $65.00 \pm 1.93$ & $0.211 \pm 0.005$ \\
\hline M2S & 200 & 300 & $77.09 \pm 1.05$ & $528.6 \pm 3.35$ & $122.57 \pm 1.71$ & $63.95 \pm 0.36$ & $0.224 \pm 0.011$ \\
\hline
\end{tabular}

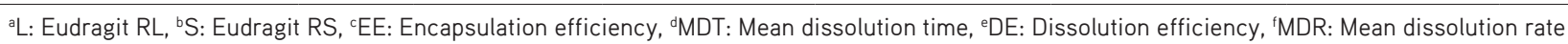




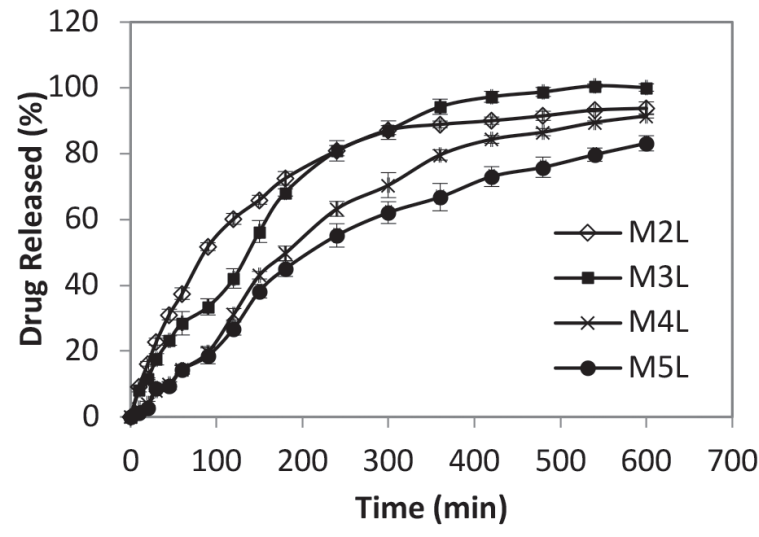

(a)

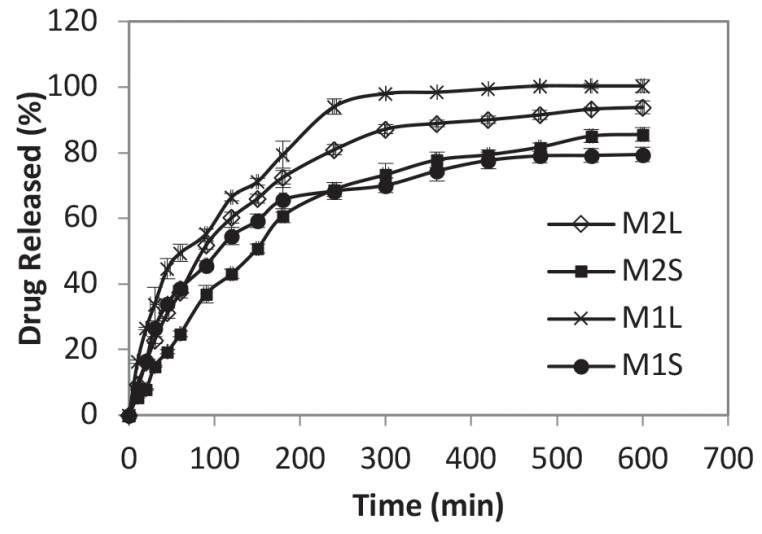

(c)

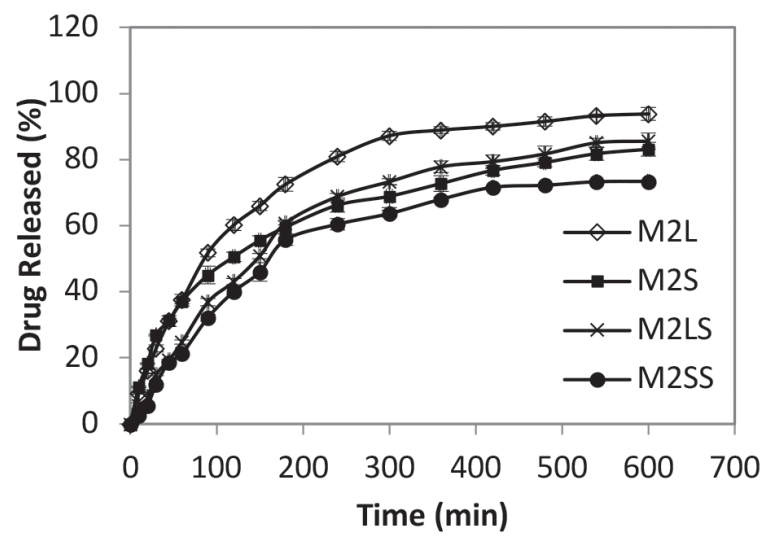

(e)

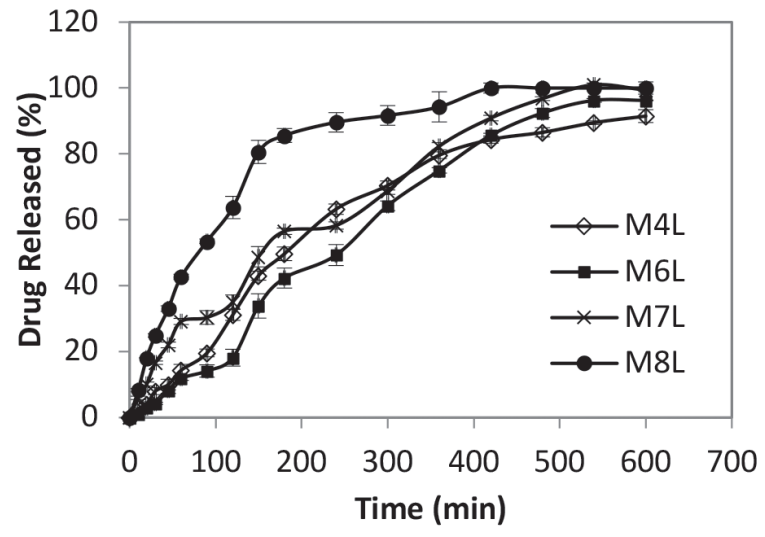

(b)

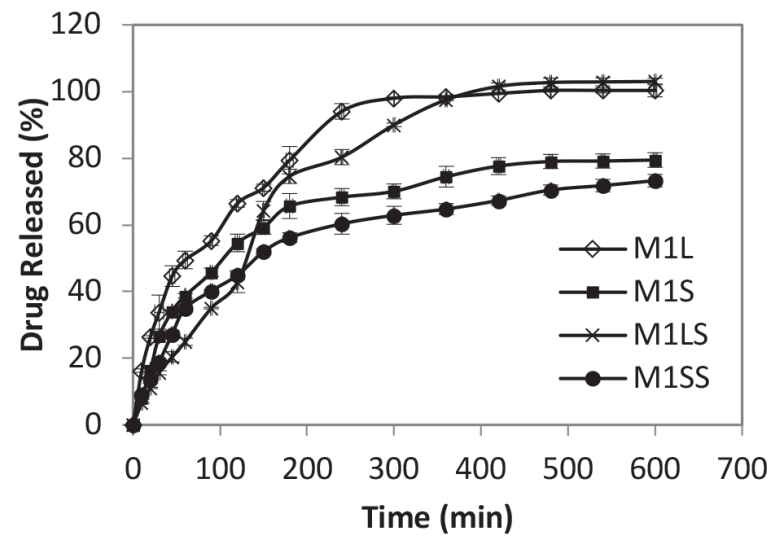

(d)

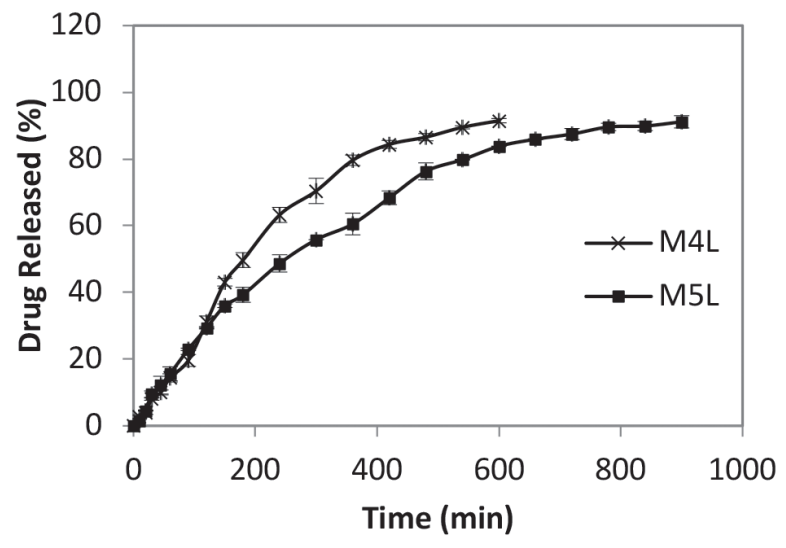

(f)

Figure 2. Release profiles of DL from (a-c) microspheres with different formulation variables in phosphate buffer (pH 7.2), (d, e) coated versus uncoated microspheres, (f) M4L in phosphate buffer $(\mathrm{pH} 7.2)$ and M5L in water $(n=3)$

area and therefore a lower release rate. A burst release of about $37 \%$ was observed for M2L during the first hour of the study, which could be attributed to the lower polymer content and particle size, as well as more drug particles on the surface layers of the microspheres.

Using higher drug concentrations with a fixed amount of polymer enhanced the drug release apparently (Figure $2 \mathrm{~b}$ ) and about $90 \%$ of $\mathrm{DL}$ was dissolved over $5 \mathrm{~h}$ from M8L
( $D E=80.78 \pm 1.91 \%$ ). Table 1 shows that MDR was significantly increased in the formulations prepared with higher drug concentrations ( $p$ <0.0001). In addition, the burst release of these microspheres was in the range of $11.88 \%-42.70 \%$. It seems that the presence of more drug particles on the surface layers of the microspheres prepared with higher drug levels enhanced the drug release rate in spite of the larger particle size..$^{15}$ In fact, reduction of the drug diffusion pathway is possible in microspheres with higher drug loading. ${ }^{25}$ Moreover, removal 
of drug particles from microspheres leads to the formation of a more porous structure, which plays an important role in accelerating drug release. ${ }^{26}$

Using various drug:polymer concentrations with the same ratio also led to microspheres with different release behavior. Based on Table 1, M7L prepared with a higher drug:polymer concentration extended the drug release more than M2L and M1L ( $p<0.001$ ), mainly due to its larger particle size. The significant decrease in the MDR value for M7L ( $p<0.001$ ) corresponds to an increase of more than $110 \mathrm{~min}$ in MDT of this formulation in comparison to M1L. All those three microspheres showed a burst release in the range of 30\%-50\%.

Figure 2c shows the release profiles of DL from microspheres prepared with Eud RL and RS. It is obvious that the drug release from the Eud RS-based microspheres was slower than that of the particles made with Eud RL. The difference observed between M1L and M1S was more evident. Based on Table 1, a reduction of more than $18 \%$ in DE and about 1.5 -fold in MDR was observed for M1S compared to M1L. The MDT values for M1S and M2S were also significantly greater than for M1L and M2L ( $p<0.001$ ). Since the mean particle size was not affected very much by the polymer type, the results obtained could be attributed to the lower permeability of Eud RS.

The effect of coating microspheres on the DL release profile is illustrated in Figures $2 \mathrm{~d}$ and $2 \mathrm{e}$. The drug release from all coated particles decreased clearly compared to the uncoated microspheres. Based on Table 2, a significant reduction in MDR and DE values was observed for coated particles. The lowest MDR was for the formulation M2SS, which was about half that of M2S. The lowest DE \% was also obtained for M2SS. A decreasing release rate was observed with increasing MDTs. A significant difference was observed between the MDTs of M1L and M1LS and also M2L and M2LS (p<0.01). Following the coating process, MDT of the microspheres with Eud RL as inner polymer was enhanced more than that of Eud RS. Furthermore, although the burst release declined for all coated microspheres, this was more noticeable for the microspheres with Eud RL as core polymer.

The results revealed that although coating of microspheres was helpful in decreasing the drug release rate, it was not as effective as using an appropriate drug:polymer concentration in the preparation process, without any coating. Formulations M5L and M6L showed the lowest MDRs and the highest MDT values among all coated and uncoated microspheres. It seems that the drug particles in the mass of microspheres were much more than the particles in the surface layers and controlling their diffusion was more important in achieving the desirable extended release behavior. However, application of a higher polymer concentration in the coating process could cause different effects.

\section{$D L$ microspheres for once- and twice-daily administrations}

Figure $2 f$ shows the release profiles of two selected formulations (M4L and M5L) in phosphate buffer solution ( $\mathrm{pH}$ 7.2) (USP test number 5) and water (USP test number 2), respectively. The results indicated that the microspheres prepared with DL: Eud $\mathrm{RL}$ ratios of 1:3 (M4L) and 1:4 (M5L) were in accordance with the USP test for DL extended release form dosing every 12 and $24 \mathrm{~h}$, respectively, without any further treatment.

The release kinetics of these formulations was investigated using three different models, i.e. zero order, first order, and the Higuchi equation. Based on the squared correlation coefficient $\left(R^{2}\right)$, the release profile of M4L was best fitted with zero order $\left(R^{2}=0.989\right)$ compared with first order and the Higuchi model $\left(R^{2}=0.973\right.$ and 0.944 , respectively). Although the $R^{2}$ values calculated for M5L based on first order (0.991) and the Higuchi equation (0.994) were higher than that of zero order (0.954), there is no evidence to specify the dominant kinetics model for this formulation.

DSC

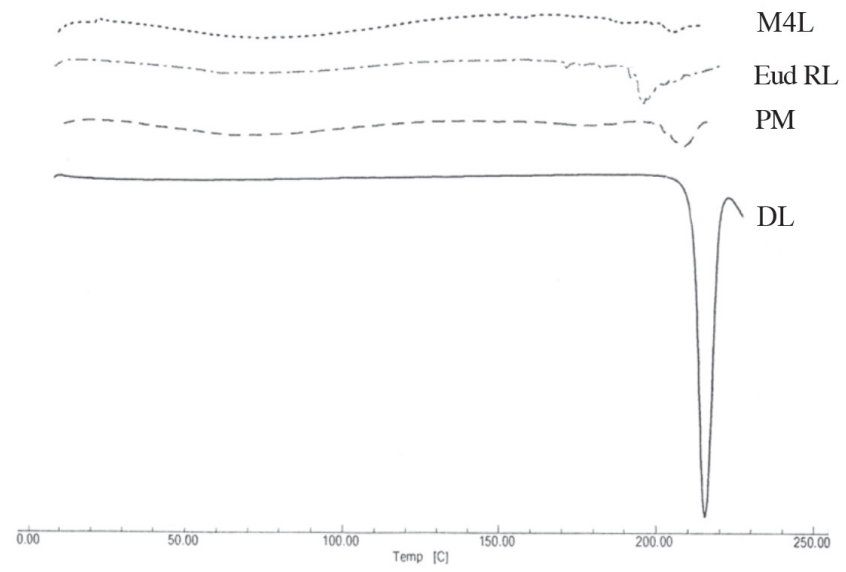

Figure 3. Differential scanning calorimetry thermograms of DL, Eudragit RL, M4L, and related physical mixture

PM: Physical mixture

Table 2. Composition and physicochemical properties of diltiazem hydrochloride microspheres coated with Eud RS (mean \pm standard deviation, $\mathrm{n}=3$ )

\begin{tabular}{lllllllll} 
Formulation & $\begin{array}{l}\text { Core drug } \\
(\mathrm{mg})\end{array}$ & Core polymer $(\mathrm{mg})$ & $\begin{array}{l}\text { Type of core } \\
\text { polymer }\end{array}$ & $\mathrm{EE}^{\mathrm{a}}(\%)$ & $\begin{array}{l}\text { Mean particle } \\
\text { size }(\mu \mathrm{m})\end{array}$ & $\mathrm{MDT}^{\mathrm{b}}(\mathrm{min})$ & $\mathrm{DE}^{\mathrm{c}}(\%)$ & $\mathrm{MDR}^{\mathrm{d}}\left(\% \mathrm{~min}^{-1}\right)$ \\
\hline M1LS & 100 & 150 & Eudragit RL & $91.99 \pm 0.82$ & $510.4 \pm 5.85$ & $118.04 \pm 3.27$ & $77.42 \pm 0.69$ & $0.195 \pm 0.004$ \\
\hline M1SS & 100 & 150 & Eudragit RS & $88.32 \pm 1.31$ & $500.2 \pm 3.05$ & $131.16 \pm 5.71$ & $57.25 \pm 1.48$ & $0.184 \pm 0.007$ \\
\hline M2LS & 200 & 300 & Eudragit RL & $82.08 \pm 2.05$ & $641.1 \pm 7.81$ & $125.18 \pm 5.32$ & $63.92 \pm 1.53$ & $0.146 \pm 0.004$ \\
\hline M2SS & 200 & 300 & Eudragit RS & $83.84 \pm 1.92$ & $610.5 \pm 3.52$ & $138.87 \pm 2.30$ & $56.33 \pm 0.20$ & $0.106 \pm 0.002$ \\
\hline
\end{tabular}

${ }^{a}$ EE: Encapsulation efficiency, ${ }^{b}$ MDT: Mean dissolution time, ${ }^{c} D E$ : Dissolution efficiency, ${ }^{d} M D R$ : Mean dissolution rate 
The DSC thermograms of DL, Eud RL, selected microsphere (M4L), and related physical mixture (PM) are depicted in Figure 3. A characteristic endotherm appeared for the drug at the onset temperature of $210.08^{\circ} \mathrm{C}$, which could be attributed to the melting of $\mathrm{DL} .{ }^{27} \mathrm{~A}$ broad peak in the range of $50-60^{\circ} \mathrm{C}$ was observed in the thermogram of Eud RL, which is related to its glass transition temperature. ${ }^{28}$ The DSC curve obtained for the microspheres presented the same thermal profile as that of the physical mixture, both containing a drug melting peak with a slight shift toward lower temperatures. These minor changes in the drug endotherm could be attributed to the presence of polymer, which lowers the drug purity. ${ }^{29}$ This result suggests no interaction between the drug and the polymer during the preparation process.

\section{CONCLUSIONS}

DL:Eud RL extended release microspheres for once- and twicedaily administration for the treatment of hypertension and angina pectoris were successfully produced in this study by a simple method of solvent evaporation using suitable formulation variables. The results confirmed that a one-step continuous emulsion solvent evaporation process was a practical technique to prepare coated microspheres with improved physical properties (especially EE \%) and reduced burst release. Using suitable drug:polymer ratios and external coating polymer concentration could modify the particle size, surface morphology, porosity, and the amount of drug particles on the surface layers, which are essential to obtain desirable results.

Conflict of Interest: No conflict of interest was declared by the authors.

\section{REFERENCES}

1. Frishman WH, Charlap S, Kimmel B, Goldberger J, Phillippides G, Klein N. Calcium-channel blockers for combined angina pectoris and systemic hypertension. Am J Cardiol. 1986;57:22-29.

2. Sultana Y, Mall S, Maurya D, Kumar D, Das M. Preparation and in vitro characterization of diltiazem hydrochloride loaded alginate microspheres. Pharm Dev Technol. 2009;14:321-331.

3. Sun $\mathrm{C}$, Liu H, Zhao X, He H, Pan W. In vitro and in vivo evaluation of a novel diltiazem hydrochloride polydispersity sustained-release system. Drug Dev Ind Pharm. 2013;39:62-66.

4. Mundargi RC, Shelke NB, Rokhade AP, Patil SA, Aminabhavi TM. Formulation and in-vitro evaluation of novel starch-based tableted microspheres for controlled release of ampicillin. Carbohydrate Polymers. 2008;71:42-53.

5. Yeo Y, Park K. Control of encapsulation efficiency and initial burst in polymeric microparticle systems. Arch Pharm Res. 2004;27:1-12.

6. Das MK, Maurya DP. Evaluation of diltiazem hydrochloride-loaded mucoadhesive microspheres prepared by emulsification-internal gelation technique. Acta Pol Pharm. 2008;65:249-259.

7. Morkhade DM. Evaluation of gum mastic (Pistacia lentiscus) as a microencapsulating and matrix forming material for sustained drug release. Asian Journal of Pharmaceutical Sciences. 2017;12:424-432.
8. Kristmundsdottir T, Gudmundsson OS, Ingvarsdottir K. Release of diltiazem from Eudragit microparticles prepared by spray-drying. Int J Pharm. 1996;137:159-165.

9. Das SK, Das NG. Preparation and in vitro dissolution profile of dual polymer (Eudragit ${ }^{\circ}$ RS100 and RL100) microparticles of diltiazem hydrochloride. J Microencapsul. 1998;15:445-452.

10. Sengel CT, Hascicek C, Gönül N. Development and in-vitro evaluation of modified release tablets including ethylcellulose microspheres loaded with diltiazem hydrochloride. J Microencapsul. 2006;23:135-152.

11. Shailesh T, Vipul P, Girishbhai J, Manish C. Preparation and in vitro evaluation of ethylcellulose coated egg albumin microspheres of diltiazem hydrochloride. J Young Pharm. 2010;2:27-34.

12. Nappinnai M, Kishore V. Formulation and evaluation of microspheres of diltiazem hydrochloride. Indian Journal of Pharmaceutical Sciences. 2007;69:511-514.

13. Sengel-Türk CT, Hascicek C, Gönül N. Microsphere-based once-daily modified release matrix tablets for oral administration in angina pectoris. J Microencapsul. 2008;25:257-266.

14. Cetin EO, Gundogdu E, Kirilmaz L. Novel microparticle drug delivery systems based on chitosan and Eudragit ${ }^{\circledR}$ RSPM to enhance diltiazem hydrochloride release property. Pharm Dev Technol. 2012;17:741-746.

15. Bolourtchian N, Karimi K, Aboofazeli R. Preparation and characterization of ibuprofen microspheres. J Microencapsul. 2005;22:529-538.

16. Lee JH, Park TG, Choi H. Effect of formulation and processing variables on the characteristics of microspheres for water-soluble drugs prepared by w/o/o double emulsion solvent diffusion method. Int Pharm. 2000;196:75-83.

17. Masaeli R, Kashi TSJ, Dinarvand R, Tahriri M, Rakhshan V, EsfandyariManesh M. Preparation, characterization and evaluation of drug release properties of simvastatin-loaded PLGA microspheres. Iran J Pharm Res 2016;15:205-211.

18. Singh V, Chaudhary AK. Preparation of Eudragit E100 microspheres by modified solvent evaporation method. Acta Pol Pharm. 2011;68:975-980.

19. Kılıçarslan M, Baykara $T$. The effect of the drug/polymer ratio on the properties of the verapamil $\mathrm{HCl}$ loaded microspheres. Int J Pharm. 2003;252:99-109.

20. Farhangi M, Dadashzadeh S, Bolourchian N. Biodegradable Gelatin Microspheres as Controlled Release Intraarticular Delivery System: The Effect of Formulation Variables. Indi J Pharm Scie. 2017;79:105-112.

21. Asare-Addo K, Šupuk E, Al-Hamidi H, Owusu-Ware S, Nokhodchi A, Conway BR. Triboelectrification and dissolution property enhancements of solid dispersions. Int J Pharm. 2015;485:306-316.

22. Yang C-Y, Tsay S-Y, Tsiang R-C. Encapsulating aspirin into a surfactantfree ethyl cellulose microsphere using non-toxic solvents by emulsion solvent-evaporation technique. J Microencapsul. 2001;18:223-236.

23. Kiliçarslan M, Baykara T. Effects of the permeability characteristics of different polymethacrylates on the pharmaceutical characteristics of verapamil hyhdrochloride-loaded microspheres. J Microencapsul. 2004;21:175-189.

24. Kim BK, Hwang SJ, Park JB, Park HJ. Preparation and characterization of drug-loaded polymethacrylate microspheres by an emulsion solvent evaporation method. J Microencapsul. 2002;19:811-822.

25. Chiao C, Price J. Formulation, preparation and dissolution characteristics of propranolol hydrochloride microspheres. J Microencapsul. 1994;11:153159. 
26. Cirpanli $Y$, Ünlü N, Çalış S, Atilla Hincal A. Formulation and in-vitro characterization of retinoic acid loaded poly (lactic-co-glycolic acid) microspheres. J microencapsul. 2005;22:877-889.

27. Al-Zoubi N, Al-obaidi G, Tashtoush B, Malamataris S. Sustained release of diltiazem $\mathrm{HCl}$ tableted after co-spray drying and physical mixing with PVAc and PVP. Drug Dev Ind Pharm. 2016;42:270-279.
28. Soltani S, Zakeri-Milani P, Barzegar-Jalali M, Jelvehgari M. Design of eudragit RL nanoparticles by nanoemulsion method as carriers for ophthalmic drug delivery of ketotifen fumarate. Iran J Basic Med Sci. 2016;19:550-560.

29. Moyano M, Broussalis A, Segall A. Thermal analysis of lipoic acid and evaluation of the compatibility with excipientes. Journal of Thermal Analysis and Calorimetry. 2009;99:631-637. 